\title{
UPAYA, LAJU TANGKAP, DAN ANALISIS USAHA PENANGKAPAN UDANG PEPEH (Metapenaeus ensis) DENGAN TUGUK BARIS (FILTERING DIVICE) DI PERAIRAN ESTUARIA SUNGAI BANYUASIN, SUMATERA SELATAN
}

\author{
Rupawan dan Emmy Dharyati \\ Peneliti pada Balai Riset Perikanan Perairan Umum, Mariana-Palembang \\ Teregistrasi I tanggal: 3 Nopember 2008; Diterima setelah perbaikan tanggal: 16 Maret 2009; \\ Disetujui terbit tanggal: 4 Mei 2009
}

\begin{abstract}
ABSTRAK
Perairan estuaria merupakan daerah pertemuan air tawar dan laut. Secara ekologi, mempunyai karakteristik yang khas dan dinamis. Estuaria sebagai daerah perangkap unsur hara yang menjadikan perairan ini relatif lebih subur. Di pantai timur Sumatera Selatan yang menghadap Selat Bangka, perairan estuaria dibentuk oleh muara Sungai Upang, Sungai Musi, Sungai Banyuasin, dan Sungai Sembilang. Di perairan ini aktivitas penangkapan ikan sangat berkembang. Tuguk baris merupakan salah satu alat tangkap yang sangat berkembang dari 13 jenis alat tangkap yang ada diperairan ini. Penelitian ini untuk mengetahui laju tangkap dan analisis usaha penangkapan udang pepeh (Metapenaeus ensis) dengan alat tangkap tuguk baris (filtering divice) telah dilakukan pada tahun 2006 di perairan estuaria Sungai Banyuasin. Data diperoleh dengan cara pengamatan dan wawancara. Hasil penelitian menunjukan bahwa upaya penangkapan berdasarkan pada jumlah hari operasi berkisar antara 8-19 hari per bulan atau 160 hari per tahun. Laju tangkap udang pepeh rata-rata $4,84 \pm 2,49 \mathrm{~kg}$ per unit jaring tuguk atau upaya, setara dengan $774,40 \mathrm{~kg}$ per jaring per tahun. Komposisi bobot hasil tangkapan adalah udang $90,46 \%$ dan ikan $9,54 \%$. Analisis operasional terhadap 34 buah jaring tuguk selama 1 tahun sebagai berikut biaya investasi awal Rp.80.240.000, total biaya tetap dan biaya operasional Rp.53.780.000, pendapatan bersih antara Rp.10.140.000-145.596.000, atau ratarata Rp.77.868.000 atau Rp.1.622.000 per kepala keluarga per bulan. B/C ratio 2,44. Ditinjau dari analisis usaha, penangkapan udang pepeh dengan alat tangkap tuguk baris menguntungkan.
\end{abstract}

KATAKUNCl: $\quad$ upaya, laju tangkap, udang pepeh, tuguk, estuari

\section{PENDAHULUAN}

Perairan estuaria merupakan daerah pertemuan air tawar dan laut. Secara ekologi, perairan estuaria mempunyai karakteristik yang khas dan sangat dinamis. Pasang surut air aut sangat berpengaruh terutama pada fluktuasi salinitas, arus air, dan keragaman jenis ikan. Hasil penelitian komposisi dan kelimpahan hasil tangkapan tuguk di Sungai Banyuasin mencapai 62 jenis terdiri atas 56 jenis ikan dan 6 jenis udang (Rupawan, 2008).

Estuaria berperan sebagai daerah perangkap unsur hara yang menjadikan perairan ini relatif subur. Supriharyono (2007) mengatakan bahwa produktivitas phytoplankton dan makrophyta di perairan estuaria dapat mencapai $500 \mathrm{~g} / \mathrm{m}^{2} / \mathrm{th}$. Selain sebagai daerah perangkap unsur hara tidak tertutup kemungkinan juga sebagai daerah perangkap bahan pencemar yang terbawa aliran air dari hulu sungai.

Di Sumatera Selatan khususya di Kabupaten Banyuasin bermuara beberapa sungai seperti Sungai Musi, Sungai Upang, Sungai Banyuasin, dan Sungai Sembilang yang berkoneksi dengan perairan laut Selat Bangka membentuk ekosistem perairan estuaria pantai timur Sumatera Selatan. Aktivitas perikanan tangkap di perairan ini sangat berkembang. Tercatat ada 13 jenis alat tangkap yaitu blad (barrier trap); tuguk (filtering divice) terdiri atas tuguk baris, tuguk apung, dan tuguk kumbang; jala (cast net); jaring ( illnet) terdiri atas jaring kantong, jaring tangsi, dan jaring cawang, trol mini, sondong, dan seser udang (scoop net), bubu kepiting (pot trap); dan rawai dasar (long line).

Alat tangkap tuguk baris salah satu jenis alat tangkap yang mempunyai peranan penting. Alat tangkap ini bersifat menetap (pasang dan tunggu), dioperasikan di perairan estuari Sungai Upang, Sungai Musi, Sungai Banyuasin, dan Sungai Sembilang dengan sasaran tangkapan utama kelompok udang penaid.

Tuguk baris dioperasikan dengan cara dipasang berbaris dengan arah memotong badan sungai, (maksimun sampai sepertiga lebar sungai, bertujuan untuk memberi ruang lalu lintas transportasi kendaraan air). Jarak antara baris tuguk dengan baris tuguk yang lain ditentukan berdasarkan pada kesepakatan antar nelayan tuguk. Di Sungai Banyuasin disepakati jarak minimal $500 \mathrm{~m}$, sebagai salah satu upaya nelayan untuk mendapatkan hasil tangkapan yang merata dan berkelanjutan. (Rupawan et al., 2007). Satu baris 


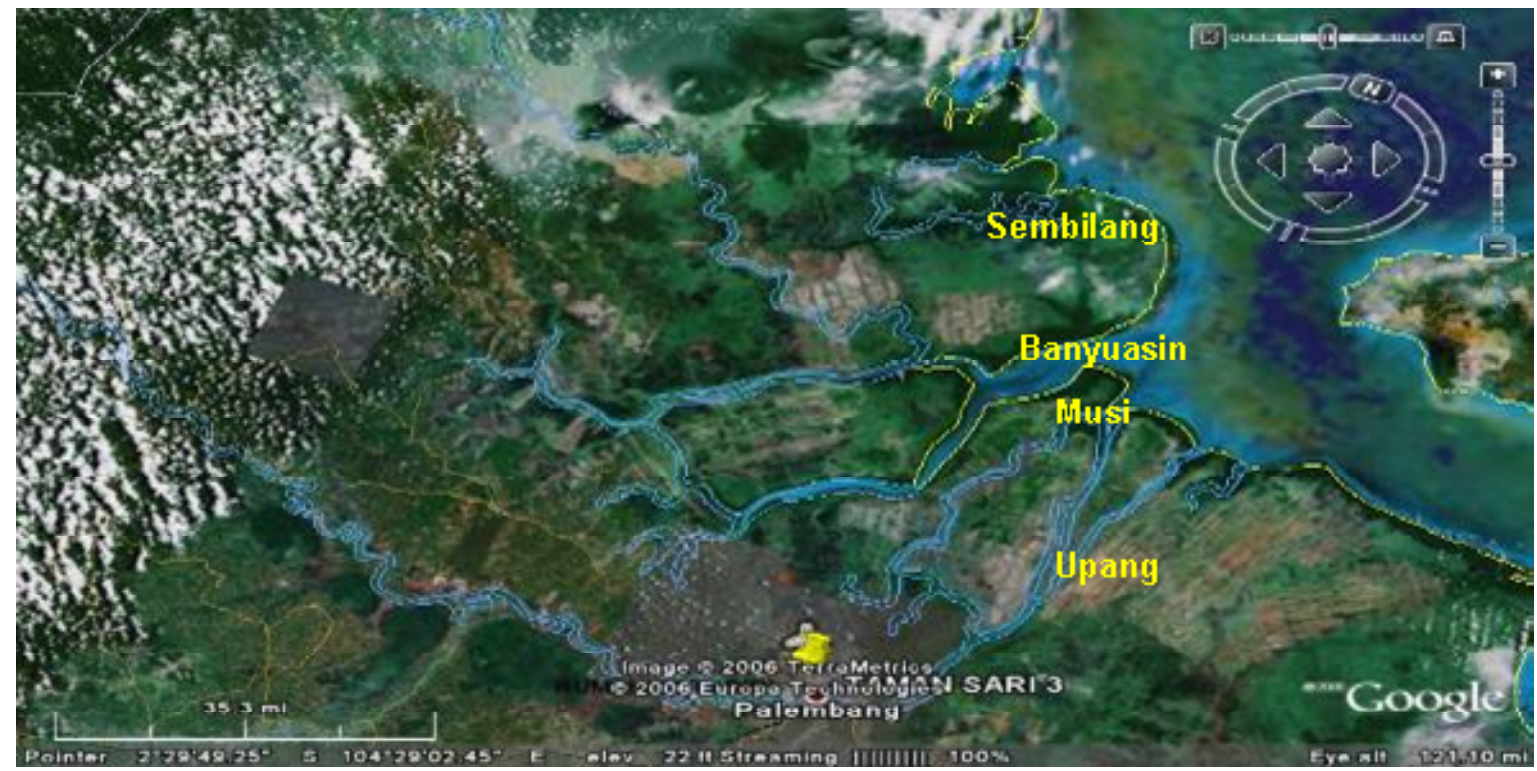

Gambar 1. Lokasi penelitian estuari Sungai Banyuasin, Kabupaten Banyuasin, Sumatera Selatan.

tuguk terdiri atas 5-40 unit jaring tuguk yang dimiliki oleh 1 orang atau lebih (berkelompok), tetapi dalam operasionalnya dilakukan secara perorangan.

Dalam rangka untuk mengetahui upaya, laju tangkap dan aspek ekonomi perikanan tuguk baris, maka telah dilakukan penelitian pada tahun 2006. Data dan informasi upaya, laju tangkap, dan analisis usaha suatu jenis alat tangkap dapat digunakan sebagai salah satu bahan evaluasi apakah alat tangkap tersebut layak dikembangkan atau dibatasi terutama bila ditinjau dari aspek sosio-ekonomi, bio-ekologi, dan aspek teknologi.

\section{BAHAN DAN METODE}

Penelitian ini dilakukan pada tahun 2006 di perairan estuari Sungai Banyuasin Kabupaten Banyuasin (Gambar 1). Data dan informasi upaya penangkapan dan laju tangkap didapat dari catatan harian hasil tangkapan 1 kelompok nelayan tuguk yang terdiri atas 4 kepala keluarga yang tergabung pada 1 baris tuguk dengan jumlah unit jaring 34 buah.

Upaya penangkapan dihitung berdasarkan pada jumlah hari operasi dengan lama waktu rendam alat 6-8 jam per hari. Laju tangkap rata-rata per jaring tuguk per hari didapat dari jumlah total hasil tangkapan per hari dibagi jumlah jaring tuguk yang beroperasi (maksimal 34 jaring).

Laju tangkap tahun yaitu rata-rata laju tangkap per hari dikali jumlah upaya 1 tahun. Pengamatan persentase hasil tangkapan udang dan ikan dilakukan dengan cara pengambilan contoh 4 kali yaitu pada waktu pelaksanaan survei lapangan. Contoh dari hasil tangkapan dipisahkan berdasarkan pada kelompok udang dan kelompok ikan, masing-masing kelompok ditimbang total.

Analisis usaha dihitung dengan menggunakan analisis deskriptif yaitu pendekatan biaya dan penerimaan (B/C) (Riyanto, 1982). Komponen biaya terdiri atas biaya tetap dan biaya operasional, biaya tetap terdiri atas biaya penyusutan alat dan biaya sewa perairan.

Biaya tetap adalah biaya yang dikeluarkan secara periodik dengan tidak melihat apakah unit alat tersebut beroperasi atau tidak. Penyusutan dihitung berdasarkan pada metode garis lurus dengan membagi harga pengadaan alat termasuk biaya pembelian bahan dan upah merakit sampai alat siap pakai sesuai dengan umur ekonomis alat yang bersangkutan. Pendapatan dihitung berdasarkan pada hasil perkalian rata-rata hasil tangkapan per upaya (trip) dikalikan dengan jumlah upaya per tahun dikalikan dengan jumlah jaring tuguk dikalikan dengan rata-rata harga jual hasil tangkapan.

\section{HASIL DAN BAHASAN}

\section{Daerah Penangkapan}

Jumlah dan sebaran alat tangkap tuguk baris di estuaria Sungai Banyuasin lebih berkembang dibanding di estuaria Sungai Upang, Sungai Musi, dan Sungai Sembilang. Di estuaria Sungai Banyuasin alat tangkap tuguk berjumlah 27 baris ( 675 unit jaring), Sungai Upang 5 baris (71 unit jaring), Sungai Musi 3 
baris (42 unit jaring), dan Sungai Sembilang 1 baris (10 unit jaring). Perbedaan jumlah yang sangat nyata ini diduga ada hubungan dengan a) perairan estuaria Sungai Banyuasin lebih terbuka, air pasang laut dapat masuk jauh lebih ke hulu, Sungai dangkal, dan lebar dengan dasar berlumpur; b) bukan alur utama transportasi air; dan c) hutan rawa pasang surut sekitar sungai relatif lebih baik. Hasil pengamatan kisaran nilai parameter fisika-kimia air yang dilakukan pada waktu surut terendah dan pasang tertinggi di lokasi operasional tuguk; $\mathrm{pH}(6,5-7,0)$, salinitas $(2,0$ $12 \mathrm{ppt})$, kecerahan $(20-85 \mathrm{~cm})$, total suspended solid $(0,385-0,472)$, kecepatan arus 0 (tenang) sampai $0,625 \mathrm{~m} /$ detik.

\section{Alat dan Musim Penangkapan}

Jenis alat tangkap tuguk baris lebih dominan dibanding jenis alat tangkap lainnya. Persaingan dengan jenis alat tangkap lain dengan sasaran tangkapan yang sama (udang pepeh) cukup longgar, tetapi persaingan untuk mendapatkan udang pepeh sesama alat tangkap tuguk cukup ketat karena jumlah unit tuguk yang banyak dan selalu bertambah.

Sasaran tangkapan utama tuguk baris adalah udang pepeh (nama lokal) atau udang dogol (Metapenaeus ensis). Udang pepeh mempunyai ukuran kecil, hidup di dasar perairan, dan gerakkannya lamban sehingga mudah tertangkap alat tuguk baris.

Tuguk dipasang dengan arah memotong badan sungai, alat tangkap pasif ditancap dan permanen, dioperasikan dengan memanfaatkan arus air pasang atau surut (Gambar 2). Waktu rendam lebih kurang selama 6-8 jam per hari operasional pada kisaran fluktuasi kecepatan arus air antara 0,216-0,625 m per detik. Udang dan ikan yang hanyut bersama arus air, masuk dalam jaring berbentuk kerucut dan terkumpul pada kantong hasil (cod end).

\section{Upaya Penangkapan}

Upaya penangkapan alat tangkap tuguk baris berdasarkan pada jumlah hari operasi (trip harian) di perairan estuari Sungai Banyuasin tahun 2006, seperti disajikan pada Gambar 3. Gambar 3 menunjukkan bahwa upaya penangkapan (trip harian) berkisar antara 8-19 hari per bulan, rata-rata 12 hari per bulan atau 160 hari per tahun.Tuguk baris dapat dioperasikan sepanjang tahun dengan puncak penangkapan musim kemarau, tahun 2006 musim kemarau pada bulan JuniOktober. Jumlah hari (trip) upaya penangkapan sangat dipengaruhi oleh tipe pasang, musim, jumlah hasil tangkapan, dan hambatan lainnya misalnya musim sampah sungai dan musim ubur-ubur. Tuguk dioperasikan pada saat hari menjelang pasang besar sampai puncak pasang besar atau pasang purnama, atau pasang induk yaitu antara 14-19 hari per bulan. Selain itu hambatan lain yang mengurangi jumlah hari operasi antara lain pada bulan musim peralihan yaitu awal musim hujan tahun 2006 (bulan NopemberDesember) banyak sampah dan tumbuhan air (eceng gondok) yang hanyut di sungai dan awal musim kemarau (bulan Maret-April) terjadi musim ubur-ubur serta bila jumlah hasil tangkapan tidak sesuai yaitu lebih rendah dari $0,3 \mathrm{~kg}$ per unit jaring per hari operasi.

\section{Hasil Tangkapan}

\section{Laju Tangkap}

Laju tangkap (hasil tangkapan per satuan alat per waktu) yaitu rata-rata jumlah hasil tangkapan udang dan ikan per jaring per hari seperti disajikan pada Tabel 1. Tabel 1 menunjukkan bahwa kisaran laju tangkap udang antara 1,2-8,2 atau rata-rata 4,84 $\pm 2,49 \mathrm{~kg}$ per jaring per hari setara dengan $774,40 \mathrm{~kg}$ per jaring per tahun dengan komposisi bobot, udang $90,46 \%$ dan ikan 9,54\%. Dengan asumsi, seluruh jaring tuguk di estuari Sungai Banyuasin (675 jaring), beroperasi

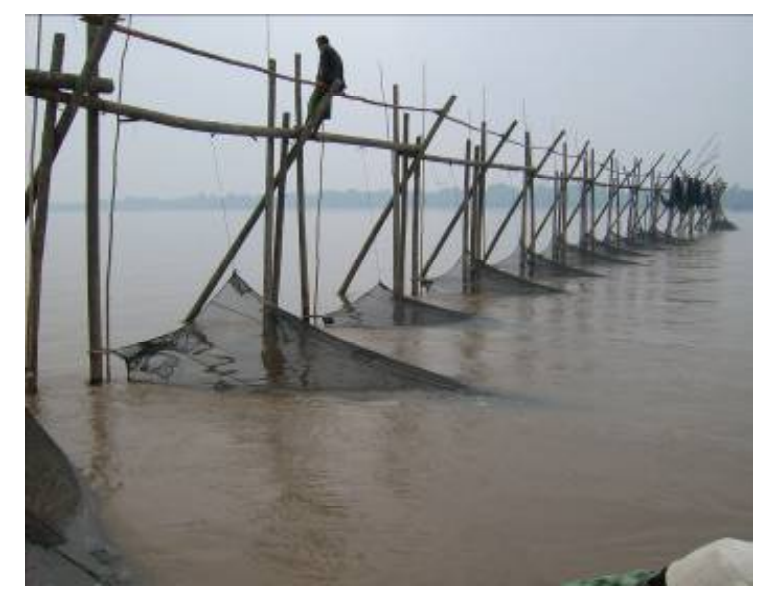

Gambar 2. Unit tuguk baris. 


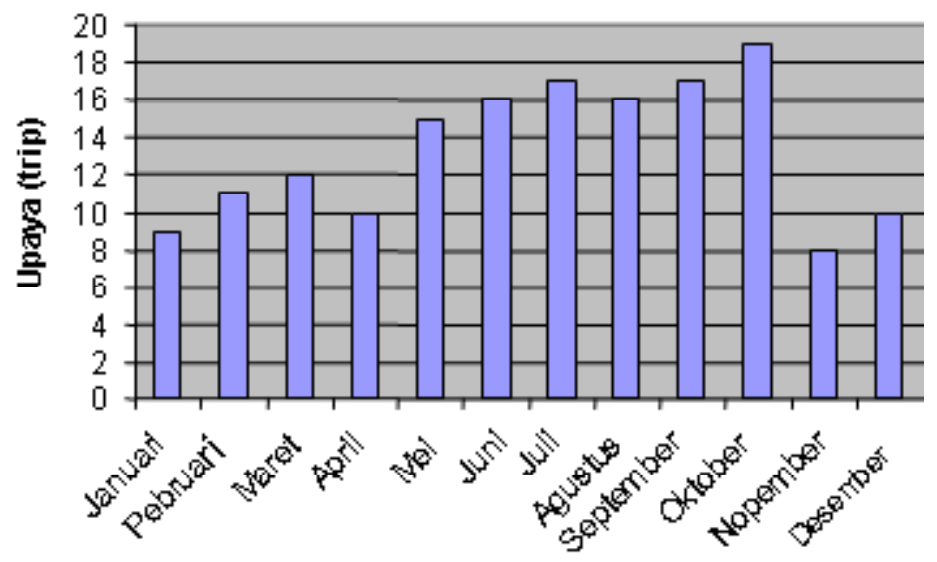

Gambar 3. Grafik upaya penangkapan tuguk baris selama tahun 2006.

Tabel 1. Rata-rata laju tangkap udang dan ikan per jaring per hari selama 12 bulan

\begin{tabular}{|c|c|c|c|c|c|}
\hline \multirow{2}{*}{ Bulan } & \multicolumn{2}{|c|}{ Hasil tangkapan (kg) } & \multirow{2}{*}{ Bulan } & \multicolumn{2}{|c|}{ Hasil tangkapan (kg) } \\
\hline & Udang & Ikan & & Udang & Ikan \\
\hline Januari & $2,5 \pm 0,43$ & * & Agustus & $7,6 \pm 0,52$ & * \\
\hline Pebuari & $4,2 \pm 0,38$ & * & September & $4,3 \pm 0,62$ & * \\
\hline Maret & $6,3 \pm 0,50$ & * & Oktober & $2,5 \pm 0,34$ & * \\
\hline April & $7,9 \pm 0,35$ & 0,76 & Nopember & $1,2 \pm 0,16$ & 0,20 \\
\hline Mei & $5,5 \pm 0,41$ & * & Desember & $1,6 \pm 0,30$ & 0,31 \\
\hline Juni & $8,2 \pm 0,45$ & * & Laju tangkap/jaring/hari & $4,84 \pm 2,49$ & 0,5125 \\
\hline Juli & $6,3 \pm 0,62$ & 0,78 & Laju tangkap/jaring/tahun & 774,4 & 81,6 \\
\hline
\end{tabular}

Keterangan: * tidak dilakukan pengamatan jumlah ikan yang tertangkap

sesuai dengan data jumlah upaya dan laju tangkap rata-rata hasil penelitian maka dapat diketahui jumlah sumber daya udang dan ikan di estuaria Sungai Banyuasin yang tertangkap dengan alat tangkap tuguk baris adalah sebagai berikut udang pepeh $522.720 \mathrm{~kg}$ dan ikan $55.080 \mathrm{~kg}$ per tahun.

Komposisi hasil tangkapan tuguk telah sesuai dengan sasaran tangkapan utama yaitu udang pepeh (Metapenaeus ensis). Udang pepeh tidak bernilai ekonomi tinggi (Rp.4.000-6.000 per kg). Seluruh hasil tangkapan digunakan sebagai bahan baku pembuatan kerupuk udang, terasi, petis, dan udang ebi (udang kering). Sedangkan hasil tangkapan ikan merupakan hasil tangkapan sampingan. Dikarenakan ukuran yang kecil, hanya sebagian kecil $( \pm 30 \%)$ yang dapat dimanfaakan untuk pembuatan ikan asin dan sisanya dibuang (Gambar 4). Laju tangkap udang baik jumlah dan persentase relatif lebih tinggi pada musim kemarau (bulan Juni-Oktober), hal ini diduga berhubungan dengan salinitas, pada musim kemarau salinitas berkisar antara 7,0-12 ppt dan kecerahan air $60-85 \mathrm{~cm}$. Keadaan sebaliknya terjadi pada musim hujan salinitas antara 2,0-5,0 ppt, beberapa jenis ikan yang hidup di air tawar ikut tertangkap.

\section{Analisis Usaha Penangkapan}

Analisis usaha penangkapan dilakukan dengan pendekatan rasio biaya dan penerimaan (B/C ratio) seperti disajikan pada Tabel 3 . Tabel 3 menunjukkan bahwa untuk operasional 34 buah jaring tuguk baris selama 1 tahun memerlukan biaya investasi awal Rp.80.240.000, total biaya tetap dan biaya operasional Rp.53.780.000, pendapatan bersih antara Rp.10.140.000-145.596.000, rata-rata Rp.77.868.000 atau Rp.1.622.000 per kepala keluarga per bulan dengan $B / C$ rasio 2,44 . Informasi $B / C$ rasio ini menunjukkan bahwa setiap satu satuan biaya yang dikeluarkan akan mendapatkan pendapatan 2,44 kali atau mendapatkan keuntungan 1,44 kali biaya yang dikeluarkan (menguntungkan). Alat tangkap tuguk baris terdiri atas 2 komponen utama yaitu kerangka tuguk yang dibuat dari kayu nibung dan jaring tuguk. Harga awal alat dihitung dari total biaya pengadaan alat termasuk pembelian bahan sampai alat siap operasional. Biaya tetap dihitung berdasarkan pada biaya penyusutan alat dan biaya sewa perairan. Perairan umum di Sumatera Selatan khususnya di Kabupaten Banyuasin tidak sepenuhnya bersifat umum karena tidak semua baik perorangan atau 
kelompok boleh melakukan kegiatan penangkapan (fishing access) untuk tujuan komersil tanpa membayar sewa perairan atau mendapat ijin dari yang membayar sewa perairan (Rupawan et al., 2007).

Biaya operasional terdiri atas biaya bahan bakar (lampu minyak atau obor) untuk rambu pada malam hari. Setiap pemilik tuguk wajib memasang pada kedua ujung unit tuguk bendera warna mencolok untuk tanda atau rambu siang hari dan lampu untuk malam hari.

Nelayan tuguk (perorangan atau kelompok) pada umumnya bertempat tinggal di dekat unit tuguk (Gambar 5). Aktivitas memasang dan memanen hasil tangkapan menggunakan perahu tanpa motor. Biaya
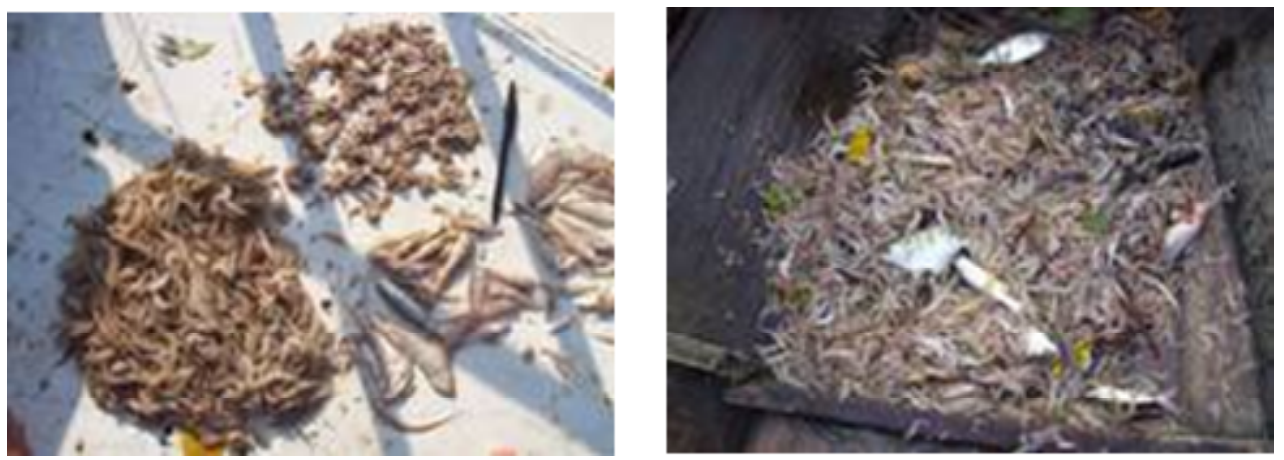

Gambar 4. Ikan dan udang hasil tangkapan tuguk baris.

Tabel 3. Komponen biaya, pendapatan, dan keuntungan usaha penangkapan 34 buah jaring tuguk selama 12 bulan

\begin{tabular}{|c|c|c|c|}
\hline Komponen & $\begin{array}{c}\text { Umur } \\
\text { ekonomis }\end{array}$ & $\begin{array}{l}\text { Harga awal } \\
\text { (Rp) }\end{array}$ & $\begin{array}{l}\text { Penyusutan/Biaya/ } \\
\text { Pendapatan (Rp) }\end{array}$ \\
\hline \multicolumn{4}{|l|}{ Biaya tetap } \\
\hline 1. Kerangka tuguk (35 rumpun $\times$ Rp.1.200.000) & 3 tahun & 42.200 .000 & 14.000 .000 \\
\hline 2. Jaring tuguk (34 buah $\times$ Rp.1.000.000) & 2 tahun & 34.000 .000 & 17.000 .000 \\
\hline 3. Perahu tanpa motor & 2 tahun & 2.000 .000 & 1.000 .000 \\
\hline \multirow[t]{2}{*}{ 4. Sewa perairan } & 1 tahun & 2.040 .000 & 2.040 .000 \\
\hline & Jumlah & 80.240 .000 & 34.040 .000 \\
\hline \multicolumn{4}{|l|}{ Biaya operasional } \\
\hline \multicolumn{3}{|l|}{$\begin{array}{l}\text { 1. Bahan bakar minyak lampu } \\
(0,5 \mathrm{~L} \times 360 \text { hari } \times \text { Rp. } 3.000)\end{array}$} & 540.000 \\
\hline \multirow{2}{*}{$\begin{array}{l}\text { 2. Biaya konsumsi dan rokok/trip operasional } \\
\text { (8 orang } \times 160 \text { hari } \times \text { Rp. } 15.000\end{array}$} & & & 19.200 .000 \\
\hline & Jum & biaya & 53.780 .000 \\
\hline \multicolumn{4}{|l|}{ Pendapatan 12 bulan } \\
\hline \multicolumn{3}{|l|}{ Minimal $=2,35 \mathrm{~kg} \times 160$ trip $\times 34$ jaring $\times$ Rp. 5.000} & 63.920 .000 \\
\hline \multicolumn{3}{|l|}{ Maksimal $=7,33 \times 160$ trip $\times 34$ jaring $\times$ Rp.5.000 } & 199.376 .000 \\
\hline \multicolumn{3}{|l|}{ Rata-rata } & 77.868 .000 \\
\hline \multicolumn{4}{|l|}{ Keuntungan } \\
\hline \multicolumn{3}{|l|}{ Minimal (Rp.63.920-Rp.53.780.000) } & 10.140 .000 \\
\hline \multicolumn{3}{|l|}{ Maksimal (Rp.199.376.000-Rp.53.780.000) } & 145.596 .000 \\
\hline \multicolumn{3}{|l|}{ Rata-rata } & 77.868 .000 \\
\hline \multicolumn{3}{|l|}{$\mathrm{B} / \mathrm{C}$ rasio } & 2.44 \\
\hline
\end{tabular}




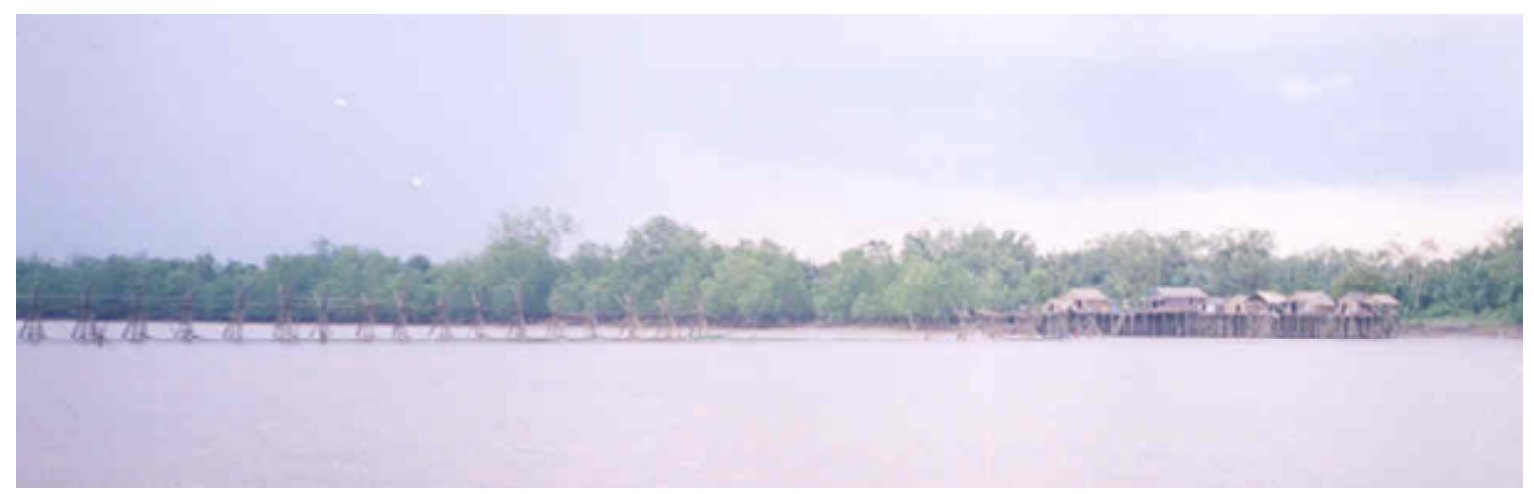

Gambar 5. Pemukiman kelompok nelayan tuguk baris di estuari Sungai Banyuasin.

\section{KESIMPULAN}

1. Upaya penangkapan berkisar antara 8-19 hari atau rata-rata 12 hari per bulan atau 160 hari per tahun. Laju tangkap udang pepeh rata-rata $4,84 \pm 2,49 \mathrm{~kg}$ per unit jaring per hari setara dengan $774,4 \mathrm{~kg}$ per jaring per tahun dengan komposisi bobot; udang $90,46 \%$ dan ikan $9,54 \%$.

2. Analisis usaha operasional 34 buah jaring tuguk baris selama 1 tahun, memerlukan biaya investasi awal Rp.80.240.000, total biaya tetap dan biaya operasional Rp.53.780.000, pendapatan bersih antara Rp.10.140.000-145.596.000, rata-rata Rp.77.868.000 atau Rp.1.622.000 per kepala keluarga per bulan dengan $\mathrm{B} / \mathrm{C}$ ratio 2,44 (menguntungkan).

\section{PERSANTUNAN}

Kegiatan dari hasil riset perikanan tangkap di perairan etuari Sungai Musi, T. A. 2006 di Balai Riset Perikanan Perairan Umum-Mariana, Palembang.

\section{DAFTAR PUSTAKA}

Riyanto, B. 1982. Dasar Dasar Pembelajaan Perusahaan. Fakultas Ekonomi. Universitas Gadja Mada. Yogyakarta.
Rupawan. 2008. Komposisi dan kelimpahan hasil tangkapan tuguk (filtering divice) di perairan estuaria yang bermuara di Selat Bangka, Sumatera Selatan. Makalah Seminar Nasional Kelautan Universitas Hang Tuah. Surabaya. 2008.

Rupawan, A. K. Gaffar, \& K. Fatah. 2007. Spesifikasi, cara operasi, dan hasil tangkapan alat tangkap tuguk di perairan estuari Sungai Musi. Prosiding Seminar Nasional Kelautan. Universitas Hang Tuah. Surabaya. 2007.

Rupawan, A. K. Gaffar, \& K. Fatah. 2007. Aktivitas dan izin penangkapan (fishing access) di perairan estuaria Selat Bangka, Sumatera Selatan. Prosiding Forum Perikanan Perairan Umum Indonesia IV. Pusat Riset Perikanan Tangkap. Palembang. 2007.

Supriharyono. 2007. Pengelolaan sumber daya perikanan yang berkesinambungan dan ramah lingkungan di wilayah pesisir. Makalah Seminar IImiah Perikanan. Program Studi Budi Daya Perairan. Fakultas Pertanian. Universitas Sriwijaya. Palembang. 2007. 